Available online at GSC Online Press Directory

GSC Biological and Pharmaceutical Sciences

e-ISSN: 2581-3250, CODEN (USA): GBPSC2

Journal homepage: https://www.gsconlinepress.com/journals/gscbps

(RESEARCH ARTICLE)

\title{
In vitro: stem cutting a simple technique for determination aggressive potential of fungal isolates causing root rot disease of grapevine
}

\author{
El- Sayed Hussein Ziedan 1, ${ }^{*}$, Moataza Mahmoud Saad 2, Khames Ahmed Hemida ${ }^{1}$, Mohamed Abd El- Aziz \\ El -Naggar ${ }^{1}$, Mostafa Helmy Mostafa ${ }^{3}$ and Magdy Gad El-Rab El- Samman ${ }^{3}$
}

${ }^{1}$ Plant Pathology Department, National Research Centre, Cairo, Egypt.
${ }^{2}$ Microbial Chemistry, Department, National Research Centre, Cairo, Egypt.
${ }^{3}$ Plant Pathology Department, Faculty of Agriculture, Ain shams University, Cairo, Egypt.

Publication history: Received on 09 April 2020; revised on 15 April 2020; accepted on 16 April 2020

Article DOI: https://doi.org/10.30574/gscbps.2020.11.1.0094

\begin{abstract}
Pathogenic soil borne fungi causing epidemic root rot disease on grapevine and high loss of plant growth and fruit yield. Fast detection of aggressive fungal isolates is the first tool for introduce selection effective a agent for management disease progress. In vitro two simple techniques based on stem cutting of grapevine i.e., mycelial growth and cell wall degrading enzymes activities were evaluated for screening of aggressive fungal isolates in comparsion with classical pathogenicity test. Fourteen isolates of fungi associated with root rot disease of grapevine plants i.e. Fusarium oxysporumi Schlechtend, Fusarium solani (Mart.) Sacc, Botryodiplodia theobromae, Rhizoctonia solani Kuhn and Macrophomina phaseolina (Tassi) Gold. were tested and pathological action on grapevine plant (Cv.crimson) under soil artificially infested by classical method with their mycelial growth,cell wall degrading enzymes activities on stem cutting of grapevine as well as each fungal isolates of shoot and root compare the control. Fungal isolate of Botryiodiplodia theobromae No. (7) was the most isolate recorded high and significant root rot (100\%) incidence and disease severity on grapevine plants followed by Fusarium avenacum isolate No. (11) and Fusarium solani isolate No. (12). Positive correlation co-efficient was observed between mycelial growth of fungal isolates tested on stem cutting of grapevine plants and root rot disease incidence and their disease severity followed by their production pectinase and cellulase enzymes. So, mycelial of fungal growth on stem cutting of grapevine is a good and simple of opportunity technique for determination aggressive degrees of fungal isolates in vitro as alternative accuracy, very short time test and very shape cost than classical pathogenicity test.
\end{abstract}

Keywords: Fungi; Grapevine; Stem cutting; Pathogenicity; Technique

\section{Introduction}

During pathogenesis process by fungi are producing several chemical metabolites in a initial time of infection plant tissue such as cell wall degrading enzymes for degradation cell wall components. The roles of cell wall degrading enzymes and disease incidence of tomato plants were reported that higher activities of cell wall degrading enzymes and wilt disease incidence of tomato were higher in susceptible cultivars of tomato than resistant cultivars sowing in soil infested by Fusarium oxysporumi f. sp. lycopersici the causal of wilt disease of tomato [1]. Over the last decade, its incidence has increased significantly in all major viticulture regions throughout the world, including South Africa, New Zealand, Italy, Australia and North America [2]; [3]; [4] and [5]. Although the disease occurs in young and mature vines, losses usually occur during the first 5 years, sometimes even during the first year after planting [6]. .For assay pathogenic potential of soil borne fungi causing root-rot on grapevine. The production cell wall degrading enzymes i.e. pectinolytic and cellulytic enzymes was more obvious in the susceptible cultivars than in the resistant ones [7],

\footnotetext{
* Corresponding author: El- Sayed Hussein Ziedan email: ziedanehe@yahoo.com, Cell Phone,00201069391163
} 
activities of hydrolytic enzymes i.e.pectin methyl esterase ( $\mathrm{PME}$ ),polygalactournase (PG) and cellulose (Cx) were higher in tissues of the susceptible strawberry cultivars infected with leaf spot pathogens than resistant cultivars. [8]in vivo production of pectinolytic enzymes was similar of all isolates of $F$. solani associated with wilt of cauliflower and apparently not correlated with pathogenic ability. However, the highly virulent isolate showed maximum of amylase activity and minimum of protease activity [9]. in vitro isolates of $F$. oxysporum causing wilt of grapevine (Cv. crimson) varied for producing lytic enzymes i.e.polygalacturonase (PG) and cellulase [10]. The aimed of this study comparative analysis between some morphological and physiological retated pathological activities of soil borne fungi causing root rot grapevine.

\section{Material and methods}

\subsection{Fungal isolates}

Fourteen fungal isolates were isolated of diseased grapevine plant by root rot and identified in Plant Pathology Department, National Research Centre, Egypt.

\subsubsection{Technique 1 Classical pathogenicity test}

The pathogenic ability of fungal isolates was carried out by classical method under greenhouse conditions at Plant Pathology Department, National Research Centre, Egypt. Plastic pots (25 cm - diameter) were sterilized by dipping in a $5 \%$ formalin solution for $15 \mathrm{~min}$. Loam sandy soil was sterilized with formalin solution (5\%), then covered with a polyethylene sheet for 7 days to retain gas, and left to dry for 2 weeks until all traces of formaldehyde disappeared. Pots were filled with sterilized soil (3.5 Kg / pot). Each isolate of tested fungi were grown on sterilized corn meal and sand medium $(75 \mathrm{~g}$ corn meal grain $+25 \mathrm{~g}$ clean pur sand $+100 \mathrm{ml}$ of water) of glass bottles. Each bottle was inoculated by disk $\left(1 \mathrm{~cm}\right.$ - diameter) taken from 7 days-old of mycelial culture of each tested fungal isolates, then incubated at $27 \pm 2{ }^{\circ} \mathrm{C}$ for 15 days. Pots were infested with each tested fungi by the rate $5 \%$ of soil weight $(\mathrm{w} / \mathrm{w})$. Pots were irrigated regularly three times a week before planting to ensure even distribution of the inoculated fungi in soil. One grapevine plant Cv. crimson (one year old) was cultivated of each pot. Ten pots were used as replicates. Ten pots free fungi infestation were cultivated as a control. Percentage of root rot disease incidence and disease severity were recorded 2.5 months after cultivation grape plants. Disease severity of grapevine plants was determined according to[10],on shoot system using two linear scale from 0 to3as follows: $0=$ healthy, $1=$ yellowish $+1 / 3$ plant wilted, $2=2 / 3$ plant wilted, $3=$ whole plant wilted and $4=$ plants dead showed sever wilt and on root on linear as scale from 0 to 3 on follows: $0=$ normal color (health) of root system , 1 = slight brown discoloration cover $25 \%$ of root system, 2 = moderate brown discoloration of root cover $50 \%$ of root system, 3 = dark cover $100 \%$ of root system.

\subsubsection{Technique 2 Fungal growth on stem cutting of grapevine}

This technique aimed to determination of mycelial colonization of fungi on stem cutting of g rapevine pieces $2 \mathrm{~cm}$ length of minds one year old were taken of healthy grapevine trees 5 years old, samples were thoroughly washed under running tap water then cut into small pieces $(2-\mathrm{cm}$ ). Pieces were surface sterilized by dipping in $1 \%$ sodium hypochlorite solution for 2 min then washing several times in sterile distilled water. Pieces were dried between two layers of sterilized filter papers then transferred to Petri dishes. Four pieces were set of each plate from fungal mycelium growth after 2 days at $272^{\circ} \mathrm{C}$ on PDA medium. Five plates were used as a replicates for each fungal isolates and five plates free fungal growth were used as a control. All Petri dishes were incubated at $27 \pm 2{ }^{\circ} \mathrm{C}$ for $5-7$ days. Mycelial growth of each fungal isolates tested were determined according to adopted linear scale (0-3) as following

$0=$ No mycelial growth on piece

$1=$ Mycelial growth covered $1 / 3$ stem cutting piece surface

2 = Mycelial growth covered $2 / 3$ stem cutting piece surface

3 = Mycelial growth covered hole stem cutting piece surface

\subsubsection{Technique 3 Cell wall degrading enzymes on stem cutting of grapevine}

This technique aimed to determination of cell wall degrading enzymes activity of fungal isolates on stem cutting of grapevine after incubation by extraction enzymes from homogenized cutting grapevine pieces in $0.1 \mathrm{M}$ sodium phosphate buffer ( $\mathrm{pH}$ 7.1) [11] at the rate of $1 / 3 \mathrm{w} / \mathrm{v}$. then centrifuged at $3000 \mathrm{rpm}$ for 15 minutes. The supernatant was used to determine cellulase enzyme activity according to [12] by taken one milliliter of $1 \% \mathrm{CMC}$ in $0.1 \mathrm{M}$ citrate buffer (pH 5.5) placed in a test tube and $1 \mathrm{ml}$ of extract was added then incubated at $50^{\circ} \mathrm{C}$ for 30 min and the reaction terminated by adding $1.5 \mathrm{ml}$ 3,5-dinitrosalisylic acid (DNSA) reagent. The tubes were heated at $100^{\circ} \mathrm{C}$ in a boiling water bath for $15 \mathrm{~min}$ and then cooled at room temperature. The absorbance was read at $540 \mathrm{~nm}$. Enzyme activity is expressed 
as $\mathrm{m}$ mol glucose released per sec-1ml-1 of enzyme extract as enzyme solution. In addation, pectinase enzymes was assay according to [12],by add $0.5 \mathrm{ml}$ of $1 \%$ pectin in $0.1 \mathrm{M}$ citrate buffer (pH 5.8) in a test tube and $0.5 \mathrm{ml}$ of cutting grapevine pieces extract was added. The reaction mixture was incubated at $50^{\circ} \mathrm{C}$ for 30 min and the reaction terminated

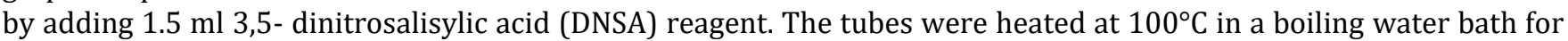
$15 \mathrm{~min}$ and then cooled at room temperature. The absorbance was read at $575 \mathrm{~nm}$. Enzyme activity is expressed as $\mathrm{M}$ mol glucose released per min-1 ml-1 of enzyme solution.

\subsection{Protein determination}

Protein concentration was determined by measuring the absorbance at $750 \mathrm{~nm}$ by the method of [13].

\subsection{Statistical analysis}

Statistical analyses of all the previously designed experiments were carried out according to (ANOVA) procedures reported by [14].

\section{Results}

\subsection{Comparative studies on pathogenicity test, fungal growth and cell wall degrading enzymes activities of fungal isolates on stem cutting in grapevine}

Data in Table (1) indicated that all fourteen fungal isolates varied of pathological action of grapevine plant mycelial growth on stem cutting and their activities of, pectinase and cellulase enzymes .Fusarium solani isolate (No.12) highly and significantly activity pectinase enzyme $(10 \mathrm{mg} / \mathrm{ml})$ followed by Fusarium oxysporumi isolate (No.6) $7.3 \mathrm{mg} / \mathrm{ml}$ then7.2 mg/ml of F.solani isolate (No.9), B. theobromaei (No.1), F. solani isolate (No.3) and B. theobromaei (No.7). F. oxysporum isolate (No.14), Fusarium avenacum isolate (No.11) and Fusarium oxysporumi isolate (No.4). Meanwhile, highly and significantly produced cellulase enzymes recorded by Fusarium avenacum isolate (No.11) followed by $B$. theobromaei isolate (No.13) then (No.7) and Fusarium oxysporumi isolate (No.6 \&10). Data in Table (1) also, indicated that Fusarium avenacum isolate (No.11) and Fusarium solani isolate (No.12) were recorded equal activities rate of two pectinase and cellulase enzymes $(12.3 \mathrm{mg} / \mathrm{ml}$ and $12.4 \mathrm{mg} / \mathrm{ml}$ respectively) followed by B. theobromaei (No.7) recorded $(10.9 \mathrm{mg} / \mathrm{ml})$ total activitiy of two enzymes. On the other hand, the lowest activities of pectinase and cellulase enzymes by Macrophomina phaseolina isolate (No.5). Data in Table (1) and Fig. (1) also, showed that the highly colonization of mycelial growth on stem cutting of grapevine by Fusarium avenacum isolate (No.11) and B. theobromaei isolate (No.7) followed by B. theobromaei isolate (No.13),Fusarium oxysporumi isolate (No.4 \& 6) and Fusarium solani isolate (No.12). In addition, data in Table (1) indicated that highly and significantly pathogenic activity of fungal for causing root rot disease incidence showed by B. theobromaei isolate (No.7) followed by Fusarium avenacum isolate (No.11), Fusarium oxysporumi isolate (No.6) then Fusarium solani isolate (No.12) and Rhizoctonia solani isolate (No.8 \& 9). Positive correlation between high pathogenic isolates on grapevine plants as shown in pathogenicity test with Fusarium avenacum isolate (No.11), Fusarium oxysporumi isolate (No.6) then Fusarium solani isolate (No.12) and their activities of pectinase and cellulase enzymes as well as colonization of mycelial growth of these isolates on stem cutting of grapevine plants. On the other hand, leak correlation between another fungal isolates tested between three criteria in this investigation. Furthermore in Table (2) as shown analysis indicated that high correlation co-efficient between mycelial growth (colonization), pectinase activity on stem cutting of grapevine and root rot incidence of grapevine under artificial infested of pots. 
Table 1 Pathogenicity test, fungal growth and cell wall degrading enzymes activities of fungal isolates on stem cutting of grapevine

\begin{tabular}{|c|c|c|c|c|c|c|c|}
\hline \multicolumn{2}{|l|}{ Fungal isolates } & \multirow{3}{*}{$\begin{array}{l}\begin{array}{l}\text { Enzymes } \\
(\mathrm{ug} / \mathrm{ml})\end{array} \\
\text { Pectinase }\end{array}$} & \multirow{3}{*}{$\begin{array}{l}\text { activities } \\
\text { Cellulase }\end{array}$} & \multirow[t]{3}{*}{$\begin{array}{l}\text { Colonization } \\
\text { rate }\end{array}$} & \multicolumn{3}{|c|}{ Root rot incidence } \\
\hline \multirow[t]{2}{*}{ Name } & \multirow[t]{2}{*}{ No } & & & & \multirow[t]{2}{*}{ Infection \% } & \multicolumn{2}{|c|}{ Disease severity } \\
\hline & & & & & & Shoot & Root \\
\hline B. theobromaei & 1 & $7.2 \mathrm{~b}$ & $5.4 \mathrm{~b}$ & $1.2 \mathrm{~cd}$ & $75.0 \mathrm{c}$ & $1.6 \mathrm{cde}$ & $1.7 \mathrm{c}$ \\
\hline R. solani & 2 & $4.7 \mathrm{~g}$ & $3.1 \mathrm{de}$ & $0.8 \mathrm{de}$ & $75.0 \mathrm{c}$ & 1.8bcde & $1.9 \mathrm{bc}$ \\
\hline F. solani & 3 & $6.9 \mathrm{bc}$ & $2.6 \mathrm{f}$ & $0.8 \mathrm{de}$ & $63.0 \mathrm{~d}$ & $1.4 \mathrm{e}$ & $1.5 \mathrm{c}$ \\
\hline F. oxysporum & 4 & $6.4 \mathrm{de}$ & $3.1 \mathrm{de}$ & $1.4 \mathrm{bc}$ & $50.0 \mathrm{e}$ & $1.6 \mathrm{cde}$ & $1.7 \mathrm{c}$ \\
\hline M. phaseolina & 5 & $1.7 \mathrm{~h}$ & $0.9 \mathrm{~g}$ & $1.0 \mathrm{~cd}$ & $62.0 \mathrm{~d}$ & $1.2 \mathrm{e}$ & $1.5 \mathrm{c}$ \\
\hline F. охуsporum & 6 & $7.3 \mathrm{~b}$ & $3.8 \mathrm{c}$ & $1.4 \mathrm{bc}$ & $87.5 b$ & $2.5 \mathrm{ab}$ & $2.6 \mathrm{ab}$ \\
\hline B. theobromaei & 7 & $6.7 \mathrm{~cd}$ & $4.2 \mathrm{c}$ & $2.6 a$ & $100.0 \mathrm{a}$ & $2.9 \mathrm{a}$ & $3.2 \mathrm{a}$ \\
\hline R. solani & 8 & $4.8 \mathrm{~g}$ & $2.5 \mathrm{f}$ & $0.5 \mathrm{e}$ & $87.5 b$ & $2.0 \mathrm{bcde}$ & $2.2 \mathrm{abc}$ \\
\hline F. solani & 9 & $7.2 \mathrm{~b}$ & $2.7 \mathrm{ef}$ & $0.8 \mathrm{de}$ & $87.5 b$ & $2.5 \mathrm{ab}$ & $2.4 \mathrm{abc}$ \\
\hline F. oxysporum & 10 & $5.5 f$ & $3.8 \mathrm{c}$ & $0.9 \mathrm{de}$ & $70.0 \mathrm{~cd}$ & $2.4 \mathrm{abc}$ & $2.5 \mathrm{abc}$ \\
\hline F. avenacum & 11 & $6.4 \mathrm{de}$ & $5.9 \mathrm{a}$ & $2.6 \mathrm{a}$ & $87.5 b$ & $2.6 \mathrm{ab}$ & $2.7 \mathrm{ab}$ \\
\hline F. solani & 12 & $10.0 \mathrm{a}$ & $2.4 \mathrm{f}$ & $1.4 \mathrm{bc}$ & $87.5 b$ & $2.5 \mathrm{ab}$ & $2.6 a b$ \\
\hline B. theobromaei & 13 & $6.2 \mathrm{e}$ & $3.2 \mathrm{~d}$ & $1.8 \mathrm{~b}$ & $75.0 \mathrm{c}$ & 2.1abcd & $2.1 \mathrm{bc}$ \\
\hline F. oxysporum & 14 & $6.5 \mathrm{cde}$ & $3.8 \mathrm{c}$ & $1.0 \mathrm{~cd}$ & $75.0 \mathrm{c}$ & $2.0 \mathrm{bcde}$ & $2.1 \mathrm{bc}$ \\
\hline Control & & $0.25 \mathrm{i}$ & $0.08 \mathrm{~h}$ & $0.0 \mathrm{f}$ & $00.0 \mathrm{f}$ & $0.0 \mathrm{f}$ & $0.0 \mathrm{~d}$ \\
\hline
\end{tabular}

Table 2 Correlation co-efficient between pathological potential, cell wall enzymes activities and fungal mycelial growth on stem cutting of grapevine

\begin{tabular}{|c|c|c|c|c|c|c|c|}
\hline & & \multirow[t]{3}{*}{ Pectinase } & \multirow[t]{3}{*}{ Cellulose } & \multirow[t]{3}{*}{ Colonization } & \multicolumn{3}{|c|}{ Root rot incidence } \\
\hline & & & & & infection & Disease & everity \\
\hline & & & & & $\%$ & shoot & root \\
\hline \multirow[t]{2}{*}{ Pectinase } & \multirow{2}{*}{$\begin{array}{l}\text {-pearson Correlation - } \\
\text { sig. }\end{array}$} & \multirow[t]{2}{*}{1} & 0.61 & 0.55 & 0.74 & 0.58 & 0.55 \\
\hline & & & 0.05 & 0.05 & 0.004 & 0.04 & 0.05 \\
\hline \multirow[t]{2}{*}{ Cellulase } & \multirow{2}{*}{$\begin{array}{l}\text {-pearson Correlation - } \\
\text { sig. }\end{array}$} & 0.62 & 1 & 0.78 & 0.65 & 0.64 & 0.62 \\
\hline & & 0.05 & & 0.002 & 0.02 & 0.02 & 0.02 \\
\hline \multirow[t]{2}{*}{ Colonization } & \multirow{2}{*}{$\begin{array}{l}\text {-pearson Correlation - } \\
\text { sig. }\end{array}$} & 0.74 & 0.65 & 1 & 0.60 & 0.90 & 0.91 \\
\hline & & 0.004 & 0.02 & & 0.04 & 0.00 & 0.00 \\
\hline \multirow[t]{2}{*}{ D.S. Shoot } & \multirow{2}{*}{$\begin{array}{l}\text {-pearson Correlation - } \\
\text { sig. }\end{array}$} & 0.58 & 0.64 & 0.55 & 0.90 & 1 & 0.99 \\
\hline & & 0.04 & 0.02 & 0.05 & 0.00 & & 0.00 \\
\hline \multirow[t]{2}{*}{ D.S. Root } & \multirow{2}{*}{$\begin{array}{l}\text {-pearson Correla D.S. = } \\
\text { disease severity } \\
\text { tion -sig. }\end{array}$} & 0.55 & 0.62 & 0.55 & 0.91 & 0.99 & 1 \\
\hline & & 0.05 & 0.02 & 0.05 & 0.00 & 0.00 & \\
\hline
\end{tabular}




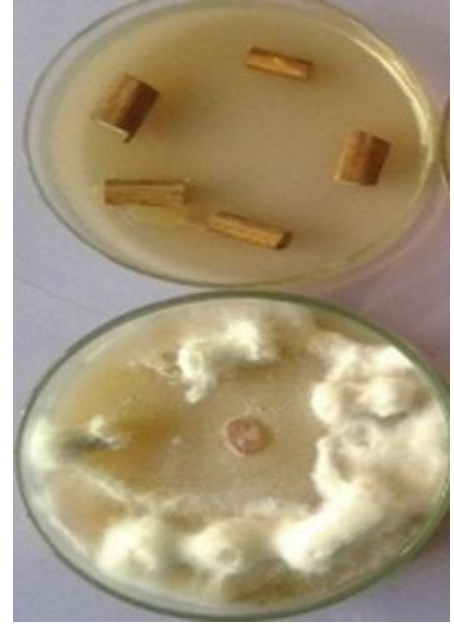

F. avenacum (No.11)

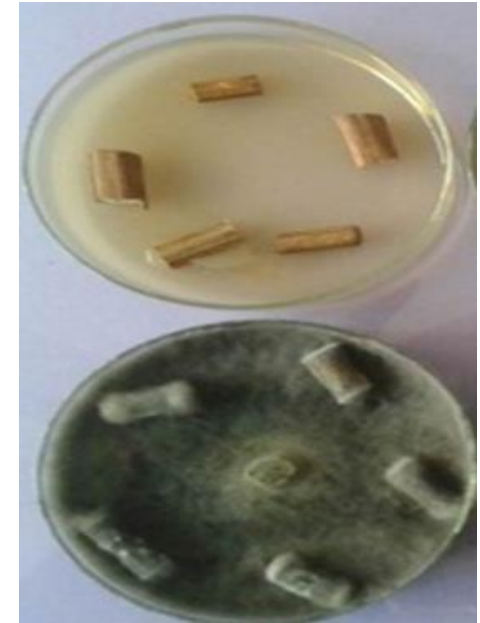

B. theobromaei (No.7)

Figure 1 Mycelial growth of aggressive fungal isolates causing root rot of grapevine plants grown on stem cutting of grapevine compare stem cutting free fungal infestation upper of each plate

\section{Discussion}

This investigation aimed to identify the alternative efficient simple method that might refect the classical pathogenicity test which need more time 2-3 months and high cost for preparation experimental requirements and conditions in greenhouse as well waiting apperance of root rot disease syndromes are included growth retardant, chlorosis, yellowish, wilt and death of shoot systems, reduction of fruit yield as well as reduction of root system mass of feeder and secondary roots. In addition, brown discoloration and maceration of main and feeder roots as well stem base of grapevine plants were observed [15]; [10]; [16], and [17]. In this study high possitve correlation of mycelial growth of fungal isolates on stem cutting of grapevine and pathogenicity test in this manner, several investigators had been evaluated pathogenicity of fungi independed on fast test growing mycelial in culture [18], [19] and [20]. Postive correlation between in vitro growth rate and pathogenicity of Ophiostomg nlmi [18] \, on the other hand, no correlation was found between colony growth rate and pathogenicity of Eucalyptus canker causal pathogen fungal isolate of Chrysoporthe austroafricana. In this manner, in vitro simple and effective screening technique of tuber piece inoculum of potato positively correlattion with black scurf disease incidence in the field caused by Rhizoctonia solani it is practical used as the rapid identification of resistant potato germplasm [21] In addition,in this study also, positive correlation between aggressive potential of fungal isolates causing root rot on grapevine plants in soil artificially infested by fungal inocula in green house i.e. Fusarium oxysporumi No. (6), Fusarium avenacum No. (11), Fusarium solani No. (12) and Botryodiplodia theobromae No. (7).These isolates were production a good amount of pectinase and cellulose at the same equal approximately of the activities of both enzymes. The roles of cell wall degrading enzymes and plant disease incidence of tomato plants were studied by [1] reported that higher activities of cell wall degrading enzymes and wilt disease incidence were higher in susceptible of tomato than resistant cultivars sowing in soil infested by Fusarium oxysporumi f. sp. lycopersici the causal of wilt disease. So mycelial growth og fungal isolates (colonization) on stem cutting of grapevine is the a simple of opportunity techniques for determination aggressive fungal isolates in vitro alternative accuracy, very short time test and very shaep cost than classical pathogenicity test.

\section{Conclusion}

Due to positive correlation between mycelial growth of fungal isolates on grapevine stem cutting as a dopted technique in vitro and classical methods in greenhouse by artificial sterilized potted soil by soil borne fungi then recorded their effect on cultivation plants after at least 3 months for determination aggressive potential of fungal isolates tested .So, in vitro, stem cutting technique is alternative accuracy, very short time test, very shaep cost and very easy assay than classical pathogenicity test in vivo. 


\section{Compliance with ethical standards}

\section{Disclosure of conflict of interest}

There is no conflict of interest among the authors.

\section{References}

[1] Srinivas C, Devi DN, Murthy KN, Mohan CD, Lakshmeesha T, Singh B, Kalagatur NK, Niranjana S, Hashem A and Alqarawi AA.(2019). Fusarium oxysporumi f. sp. lycopersici causal agent of vascular wilt disease of tomato: Biology to diversity-A review. Saudi Journal of Biological Sciences, 26 (7), 1315-1324.

[2] Van Niekerk JM, Crous PW, Groenewald J, Fourie PH and Halleen F. (2004). DNA phylogeny, morphology and pathogenicity of Botryosphaeria species on grapevines. Mycologia, 96(4), 781-798.

[3] Petit E and Gubler WD. (2005). Characterization of Cylindrocarpon species, the cause of black foot disease of grapevine in California. Plant Disease, 89(10), 1051-1059.

[4] Alaniz S, Armengol J, León M, García-Jiménez J and Abad-Campos P. (2009). Analysis of genetic and virulence diversity of Cylindrocarpon liriodendri and $C$. macrodidymum associated with black foot disease of grapevine. Mycological research, 113 (1), 16-23.

[5] Van Wyk M, Heath RN, Tarigan M, Vermeulen M and Wingfield MJ. (2010). Comparison of procedures to evaluate the pathogenicity of Ceratocystis fimbriata sensu lato isolates from Eucalyptus in South Africa. Southern Forests, 72(2), 57-62.

[6] Halleen F, Schroers H-J, Groenewald JZ, Rego C, Oliveira H and Crous PW. (2006). Neonectria liriodendri sp. nov., the main causal agent of black foot disease of grapevines. Studies in Mycology, 55, 227-234.

[7] Hoondal G, Tiwari R, Tewari R, Dahiya N and Beg Q. (2002). Microbial alkaline pectinases and their industrial applications: a review. Applied Microbiology and Biotechnology, 59(4-5), 409-418.

[8] Abou-Elaid H, El-Naggar M, Abdel-Kareem F, El-Deeb H and El-Shahawy I. (2014). Field Application with biocontrol agents for controlling root-rot disease of grapevine (Vitis vinifera L.). Middle East j, 3(4), 775-781.

[9] Kaur G and Padmaja V. (2009). Relationships among activities of extracellular enzyme production and virulence against Helicoverpa armigera in Beauveria bassiana. Journal of Basic Microbiology, 49(3), 264-274.

[10] Ziedan E-SH, Embaby E-SM and Farrag ES. (2011). First record of Fusarium vascular wilt on grapevine in Egypt. Archives of Phytopathology and Plant Protection, 44(17), 1719-1727.

[11] EL-Mahdy AA, Ibrahim AE-WA and Attia N. (2017).Impact of some seed treatments on teosinte seed quality under laboratory and field conditions. Journal of Plant Production, 8(2), 277-282.

[12] Sharma A, Tewari R, Rana SS, Soni R and Soni SK. (2016). Cellulases: classification, methods of determination and industrial applications. Applied Biochemistry and Biotechnology, 179 (8), 1346-1380.

[13] Bradford MM. (1976). A rapid and sensitive method for the quantitation of microgram quantities of protein utilizing the principle of protein-dye binding. Analytical Biochemistry, 72(1-2), 248-254.

[14] Hoshmand R. (2017). Statistical methods for environmental and agricultural sciences. CRC press.

[15] Gutter W, Baumgartner K, Browne G, Eskalen A, Latham SR, Petit E and Bayramian L. (2004). Root diseases of grapevines in California and their control. Australasian Plant Pathology, 3 (2), 157-165.

[16] Vinayarani G and Prakash H. (2018). Growth promoting rhizospheric and endophytic bacteria from Curcuma longa L. as biocontrol agents against rhizome rot and leaf blight diseases. The Plant Pathology Journal, 34 (3), 218.

[17] Hemida K, Ziedan E, El-Saman M, El-Naggar M and Mostafa HM. (2017). Etiology of fungi associated with grapevine decline and their pathological potential. Arab Universities Journal of Agricultural Sciences, 25(2), 355365.

[18] Brasier C and Webber J. (1987). Positive correlations between in vitro growth rate and pathogenesis in Ophiostoma ulmi. Plant Pathology, 36(4), 462-466. 
[19] Enebak S, MacDonald W and Hillman B. (1994). Effect of dsRNA associated with isolates of Cryphonectria parasitica from the central appalachians and their relatedness to other dsRNAs from North America and Europe. Phytopathology, 84(5), 528-534.

[20] Fulbright D. (1984). Effect of eliminating dsRNA in hypovirulent Endothia parasitica. Phytopathology, 74(6), 722724.

[21] Zhang X-Y, Yu X-X, Yu Z, Xue Y-F and Qi L-P. (2014). A simple method based on laboratory inoculum and field inoculum for evaluating potato resistance to black scurf caused by Rhizoctonia solani. Breeding Science, 64(2), 156-163.

\section{How to cite this article}

Ziedan EH, Saad (Moataza) M, Hemida KA,El-Naggar MA, Mostafa HM and El-Samman MG. (2020). In vitro: stem cutting a simple technique for determination aggressive potential of fungal isolates causing root rot of grapevine GSC Biological and Pharmaceutical Sciences, 11(1), 141-147. 